\title{
Re-imagining the Borders of US Security after 9/11: Securitization, Risk and the Creation of the Department of Homeland Security ${ }^{1}$
}

This is a post-peer-review, pre-copyedit version of an article published in Globalizations. The definitive publisher-authenticated version 'Re-imagining the Borders of US Security after 9/11: Securitization, Risk and the Creation of the Department of Homeland Security', Globalizations Vol. 4, No. 3 (2007): 385-397, is available online at:

http://dx.doi.org/10.1080/14747730701532567

Bryan Mabee

School of Politics and International Relations

Queen Mary, University of London

Mile End Road

London E1 4NS

UK

\begin{abstract}
The articulation of international and transnational terrorism as a key issue in US security policy, as a result of the 9/11 attacks, has not only led to a policy rethink, it has also included a bureaucratic shift within the US, showing a re-thinking of the role of borders within US security policy. Drawing substantively on the 'securitisation' approach to security studies, the article analyses the discourse of US security in order to examine the founding of the Department of Homeland Security, noting that its mission provides a new way of providing 'borders' for US national security. The securitisation of terrorism is therefore not only represented by marking terrorism as a security issue, it is also solidified in the organisation of security policy-making within the US state. As such, the impact of a 'war on terror' provides an important moment for analysing the re-articulation of what security is in the US, and, in theoretical terms, for reaffirming the importance of a relationship between the production of threat and the institutionalisation of threat response.
\end{abstract}

The creation of the Department of Homeland Security (DHS) was a monumental act of restructuring of the architecture of US government. The creation of the DHS involved an enormous reorganization of government bureaucracy: consolidating 22 government agencies involving 180,000 employees, for the purpose of, as President Bush stated, 'ensuring that our efforts to defend this country are comprehensive and united' (Bush, 2002). Often compared in its scope to the National Security Act of $1947,{ }^{2}$ the DHS also promised to have as important an impact in defining US security in the future. ${ }^{3}$ While not a lone institutional feature of the 'war on terror', it was and remains the new 'home front'. In essence, the 9/11 attacks have led to the reformulation of the 'national security state', possibly beyond what the architects of the National Security Act would have imagined (or desired). 
The impact of a 'war on terror' is important in many ways for scholars of international relations: for what it means generally for international security, for the kinds of changes that have been implemented in US grand strategy, and for specific analyses of the efficacy of antiterror policy making. However, it is also an important moment for analysing the rearticulation of what security is in the US, and, in theoretical terms, for reaffirming the importance of a relationship between the production of threat and the institutionalisation of threat response.

When external threat is linked to monumental (and often catastrophic) events, it can lead to historical openings for the rearticulating of security. Although this is in some ways quite obvious, the particular ways in which threat is produced, or securitised, in these moments also can lead to the re-articulation of security actors (i.e. those that have the power to respond to threats) through the institutionalisation of a particular response to threat. That is to say that actors in security policy-making in various governmental bureaucracies can have fundamental shifts in the way security is approached as a result of institutionalising new ways of framing security. As such, the articulation of international and transnational terrorism as a key issue in US security policy, as a result of the 9/11 attacks, has not only led to a policy rethink, it has also included a bureaucratic shift within the US, showing a re-thinking of the role of borders within US security policy. The securitisation of terrorism is therefore not only represented by marking terrorism as a security issue, it is also solidified in the organisation of security policy-making within the US state.

The article will further this argument in three stages. First, the analyses of the conventional discourse of security studies concerning 9/11 will be briefly examined, in order to provide a critique that brings ideational factors back in. The account here draws substantively on the 'securitisation' approach (Buzan, Waever and De Wilde, 1998), though with some modifications to better theorise the institutionalisation of threat. Second, the discourse of US security will be examined in order to look at the way in which the moment of 9/11 became folded into the discourse of US security, drawing from past experience, but also in an attempt to move beyond the Cold War national security state. Finally, the founding of the DHS will be discussed, especially in terms of how its mission provides a new way of 
providing 'borders' for US national security. The 9/11 attacks on the United States provided an opportunity for a redefining of national security in the US, that institutionally manifested itself in the DHS. While previously threats to the US were seen as external, the terrorist attacks showed the risk inherent in increasing transnationalism, which allowed for the institutionalisation of the protection of borders through policing measures, in addition to the well-known and controversial moves towards the pre-emptive use of military force.

\section{Constructing Threats, Building Institutions}

Two main views have dominated the conventional security discourse on the $9 / 11$ attacks: that nothing has changed; or that external threats require internal policy changes. The first view was made by a number of prominent realists, attempting to put the events of $9 / 11$ into a broader historical perspective. ${ }^{4}$ The problem with this view is that it misses both the symbolic and discursive value of the action: that is, in a sense, it is important because people believe it to be, and treat it as if it is. In a broader manner, it is a shortcoming of the realist theory to not take internal changes in policy very seriously: for realists it is really relations between states that matter, and not the specific policies one state enacts. The second view takes the events seriously as a turning point, and is more focused on policy options. In this view, the 9/11 events have shown the materialisation of a dramatic new threat, and thus needs new responses. The main problem with this approach is that it refuses to show how such actions are discursively constituted and also have broader institutional contexts in their formulation.

Constructivism has challenged conventional approaches to international security by adding a normative dimension: that ideational factors constitute social relations (e.g. Farrell, 2000; Hopf, 1998; Katzenstein, 1996; c.f. Guzzini, 2000; Weldes et al. 1999). Constructivist approaches to security studies have mainly dealt with the creation and influence of international norms, at either the international or domestic level. In terms of the former, they have shown how the shared ideas of state actors shape the practice of international relations: for example in terms of how shared beliefs about nuclear weapons have created an effective 'nuclear taboo'; or how notions of community have created areas of inter-state relations where there is little chance of war (Tannenwald, 1999; Adler and Barnett, 1998). The latter 
group of scholars have mainly pointed to the development of 'national styles' or approaches to security, exemplified by the rich studies of military organisational cultures, and studies of national strategic cultures (Berger, 1996; Johnston, 1995; Kier, 1996; cf. Desch, 1998).

Overall, the question of agency in such studies has been underdeveloped, despite claims about the 'mutual constitution' of agents and structures, which hinders the analysis. ${ }^{5}$ As Checkel notes, 'constructivists, despite their arguments about mutually constituting agents and structures, have advanced a structure-centred approach in their empirical work' (1999: 342). The structural nature of the work has manifested itself in the study of norms which structure actors' behaviour. While important, the study of security norms has ignored the ways in which actors construct ideas about what threats are, and what security itself is.

The hallmark of the 'Copenhagen School' has been a close understanding of the process of creating discursive constructions of threat, while also conveying a rich understanding of agency, potentially not just confined to states. (Buzan et al., 1998; Waever, 1995; Waever et al., 1993). The 'securitisation' approach put forward by the Copenhagen school primarily examines the manner in which threats are identified and responded to. The key to the approach is how discursive moves by 'securitising actors' bring a perceived threat out of the area of normal politics and into the area of security, where it is seen as a kind of 'emergency measure': 'the invocation of security has been the key to legitimising the use of force, but more generally it has opened the way for the state to mobilize, or to take special powers, to handle existential threats' (Buzan et al., 1998: 21). ${ }^{6}$ Overall, the securitisation approach sees the identification of security threats as an intersubjective process, highlighting the influence of ideational factors on policy-making. The importance of highlighting the role of ideas in such a manner is to show that the belief in a particular discourse of threat can lead to the implementation of measures to deal with the threat, regardless of whether the threat is objective or not. ${ }^{7}$

While securitisation theory contains a number of important insights, a real shortcoming arises from the inability to distinguish between different types of threats and their possible impacts. A distinction is proposed here between what we can refer to as threat objects and threat ideas, where objects refer to specific 'things' (e.g. terrorism), and ideas refer to the 
broader context (e.g. international structure) ${ }^{8}$ Overall, the category of ideas is meant to convey a response to a broader context, that may necessitate the institutionalisation of new security actors, those who have the power to make securitising moves within a specific political context. It is in this sense a distinct type of securitisation. More broadly, the role of ideas in this context changes from being immanent to transcendent, in that the causal role of ideational power moves from reproducing the institutional status quo, to transforming it (Mann, 1986: 22-24).

Such a distinction seems crucial in explaining the broader context of securitisation, and especially in terms of how the securitisation of broad contexts often becomes institutionalised. Buzan et al. do discuss how persistent threats tend to become institutionalised, and this is especially prominent in the military sector, 'where states have long endured threats of armed coercion or invasion and in response have built up standing bureaucracies, procedures and military establishments to deal with those threats' (Buzan et al., 1998: 27-28). However, this does not mean that these are not securitised, for in a sense that they have become normalised. They were most likely first established through a securitising move, and are often continuously justified through the discourse of security (Buzan et al., 1998: 28). The recognition of this entrenched securitisation is important, as it shows attention to not just specific threats, but also to a broader threat environment; e.g. the general threat of armed attack versus a specific type of attack. It is precisely this area that becomes important in the case of transforming security bureaucracies, and deserves more discussion.

The creation of new state security institutions, and their reproduction, is dependent to a certain extent on the existence of a discourse about their necessity and actual role. ${ }^{9}$ While state theorists have pointed to important elements in terms of understanding the relationship between the state and the international and domestic realms (Hobson, 2000), there is a need for a better understanding of the role of ideas. As Hay states, 'ideas often hold the key to unlock political dynamics - as change in policy is often preceded by changes in the ideas informing policy and as the ability to orchestrate shifts in societal preferences may play a crucial role in quickening the pace, altering the trajectory or raising the stakes of institutional 
reform' (Hay, 2002: 194). In these instances, it is not just that interests get pursued in different ways, it is that interests themselves become redefined.

Normal bouts of securitisation are usually contained within a particular discursive framework of what constitutes danger, and how this can be responded to. Despite securitisation moves being seen as moving beyond 'normal' politics, they still can represent particular procedural reactions to specified dangers. However, in exceptional circumstances, such understandings can be effectively challenged, leading to new discursive mappings of the security environment. Such openings often occur in moments of momentous change or uncertainty (Goldstein and Keohane, 1993; Ikenberry, 1993, 2001). It is in these moments when the possibility for a new discursive mapping of the international realm is most likely, leading to a securitisation of a new threat environment. As Hay points out, 'ideas provide the point of mediation between actors and their environment' (Hay, 2002: 209-210). As such, exceptional moments can lead to reformulations by and restructuring of security actors within the state, which can also lead to an overall change and institutionalisation of what security is within that state. Such institutionalisation, materially manifested in the security bureaucracy, sets the context within which security policy can be formulated, setting distinct limits on both thinking and responses. As such, institutions can develop their own 'logics of appropriateness' which provide the boundaries within which actors can operate (March and Olsen, 1994, 1998).

The development of a deep institutionalisation of a particular securitised threat leads over time to a reification of a particular kind of state, which is geared institutionally towards specific ways of both deciding what is a threat and responding to threats. The institutionalisation of securitisation also leads to its normalisation. As Goldstein and Keohane point out, 'once ideas have influenced institutional design, their influence will be reflected in the incentives of those in the organization and those whose interests are served by it' (Goldstein and Keohane, 1993: 20). For example, when states are institutionally geared towards militarised competition, as the US and Soviet Union were during the Cold War, these 'extreme measures' become institutionalised, and therefore become normalised. ${ }^{10}$ 
Overall, the manner in which security actors are identified needs to be expanded to better understand the process of securitisation at the state level, better appreciate the connections between state, society and the international, and to comprehend the process of the institutionalisation and reproduction of security actors and security bureaucracies. State security bureaucracies play a powerful role in institutionalising ideas about the scope of security, and can, in the long-term, both change the idea of the ideology of national security and how it is pursued. The following section operationalises this expanded understanding of securitisation, by examining the impact of $9 / 11$ on the creation of the Department of Homeland Security.

\section{9/11 and the Discourse of US Security}

The security environment in the US in the 1940s was heavily defined by the events at Pearl Harbor on December 7, 1941 (which President Roosevelt described as 'a date which will live in infamy'). Discussions in Congress regarding the unification of the armed services often were accompanied by calls to 'remember Pearl Harbor' (Hogan, 1998). When the new dimension of Soviet-US relations was added to this mix, the institutionalisation of the national security state was not far off. Kennan's Long Telegram, the Truman Doctrine, etc., all coalesced into an antagonistic security discourse that framed the external security environment in the context of what had become a major historical opening. 'Remember Pearl Harbor' so that we will not get caught out again. By the mid-1940s, the Soviet Union became the potential competitor who might provide another surprise (Gaddis, 1987). The fusion of civil-military functions found in the 1947 National Security Act, and the resultant security complex found in the National Security Council and (eventually) the Department of Defense, proved themselves able to the task, producing one of the defining strategic documents of the Cold War, NSC-68, in 1950.

The early Cold War provides a demonstration of how a symbolic event can be utilised to inform the securitisation process. Pearl Harbor, and its connotations of surprise, unreadiness, and lack of organisation, were utilised to frame the context relations with the Soviet Union, which helped in the creation of new security actors, and a new discourse of US security. 
Additionally both of these key events played into a longer-term narrative concerning the perceived invulnerability of American borders; as Gaddis explains, 'the American ideal . . . had been to insulate domestic life from a violent external world' (Gaddis, 2004: 9; c.f. Leffler, 2003). While making comparisons between historical moments can often be risky, two features are important: one is the explicit linkages made to this past by policy makers in terms of lessons of the past; second, and more abstractly, is the relationship between the security discourse and the creation of security institutions. The former will be taken further here, while the latter will be taken up in the next section.

Linking $9 / 11$ to a discourse of securitisation is not difficult. The events themselves were horrific, and had the added impact of being continually repeated on television, embedding them in the public consciousness. ${ }^{11}$ As Morgan points out, in a similar vein, 'in the past, planning and preparations for armed conflict seemed implicitly to assume that US territory would remain a sanctuary. Shattering a complacent sense of invulnerability, the bombing moved these threats to salience in the public perception' (Morgan, 2004: 11). The 9/11 Commission also drew the parallel to Pearl Harbor, especially focussing in on how it was possibly even worse:

While by no means as threatening as Japan's act of war, the 9/11 attack was in some ways more devastating. It was carried out by a tiny group of people, not enough to man a full platoon. Measured on a governmental scale, the resources behind it were trivial. The group itself was dispatched by an organization based in one of the poorest, most remote, and least industrialized countries on earth. This organization recruited a mixture of young fanatics and highly educated zealots who could not find suitable places in their home societies or were driven from them (9/11 Commission, 2004: 339-340).

Further focusing on statements from the Executive branch, it can be easily shown that 9/11 not only became crucial in a securitisation process concerning terrorism, it also solidified the idea of a new environment of threat, that would need unprecedented kinds of action, including the types of emergency measures described by the securitisation approach, but also the development of new security institutions. In a powerful and uncompromising address to a joint session of Congress and the nation on September 20, 2001, President Bush explicitly appealed to the event framed in terms of the uniqueness of the event: 
on September the $11^{\text {th }}$, enemies of freedom committed an act of war against our country. Americans have known wars - but for the past 136 years, they have been wars on foreign soil, except for one Sunday in 1941. Americans have known the casualties of war - but not at the center of a great city on a peaceful morning. Americans have known surprise attacks - but never before on thousands of civilians. All of this was brought upon us on a single day and night fell on a different world, a world where freedom itself is under attack (Bush, 2001).

This statement, very much captures the sentiment of surprise, the comparison to Pearl Harbor, their almost unprecedented nature, and the continuing sense of danger and threat.

The nature of the attacks therefore required a new kind of response. Up until that point, the threat of the 'new' terrorism had been folded into existing security discourses and procedures. ${ }^{12}$ However, as President Bush continued,

our response involves far more than instant retaliation and isolated strikes. Americans should not expect one battle, but a lengthy campaign, unlike any other we have seen. It may include dramatic strikes, visible on TV, and covert operations, secret even in success. . . And we will pursue nations that provide aid or safe haven to terrorism. Every nation, in every region, now has a decision to make. Either you are with us, or you are against us (Bush, 2001).

The identification of new means and ends, new ways of conducting international relations, all fit in with the move to 'emergency' measures.

One of the most important measures, however, came in the institutionalisation of the domestic response. In the Speech to congress, President Bush announced the creation of an executive level position, the Office of Homeland Security. While initially a 'terrorism Czar', the position a year later became the head of a newly organised US government bureaucracy, through the Homeland Security Act. As President Bush stated at the signing of the Act, 'today, we are taking historic action to defend the United States and protect our citizens against the dangers of a new era' (Bush, 2002). Repeating the idea of a new era and new environment of security, the President continued:

We're fighting a new kind of war against determined enemies. And public servants long into the future will bear the responsibility to defend Americans against terror. This administration and this Congress have the duty of putting that system into place. We will fulfil that duty. With the Homeland Security Act, we're doing everything we can to protect America. We're showing the resolve of this great nation to defend our freedom, our security and our way of life (Bush, 2002). 
The official discourse of 9/11 and the resultant 'war on terror' effectively securitised not only international terrorism, but a new environment of security. 9/11 symbolically fulfilled the role that Pearl Harbor did 60 years previously: to warn Americans of the dangers of a new era, of a new environment of threat. Such an environment required a new response, and effectively, a new concept of security. As the President stated, 'we recognize our greatest security is found in the relentless pursuit of these cold-blooded killers. Yet, because terrorists are targeting America, the front of the new war is here in America. Our life has changed and changed in dramatic fashion on September the 11 ${ }^{\text {th }}, 2001^{\prime}$ (Bush, 2002).

The audience did not need much convincing of the salience of the threat of terrorism. The impassioned speeches by Bush certainly changed the perception of a foreign policy novice, who had also seemed overawed at the moment of the attacks. The repeated airing of the attacks on TV helped to further dramatise and provide a constant reproduction of the symbol of threat. As such, the audience of securitisation, both in government and out, were not a hard case, and 'emergency measures' certainly seemed appropriate in light of events. ${ }^{13}$ This is not to say that the specific response - a 'war on terror' based on pre-emption and heightened homeland security - was the only response. What is important is that the legitimation of the new discourse of security focused on terrorism easily allowed for a new policy response that was further institutionalised through a restructuring of the security bureaucracy of the US state.

\section{The Department of Homeland Security and the Global Risk Environment}

The creation of the DHS was, as stated in the introduction, a major restructuring of the architecture of the US government. ${ }^{14}$ Prior to $9 / 11$, there was little motivation to reform the Cold War security system, as institutional inertia and the lack of a massive external threat led to the continuation of what already seemed to be working. As Stuart suggests, 'absent a crisis comparable to Pearl Harbour, the American people were content to focus on their 401k's and stock options' (Stuart, 2003: 306-307). Although there had been a number of adjustments to the network of security institutions, such as the Goldwater-Nichols reform of the Department of Defense (Locher, 2003), and President Clinton's creation of a National Economic Council 
(NEC) which mirrored the NSC in organisation, security arrangements still had a distinctly Cold War flavour.

The DHS itself was created to integrate numerous diverse agencies that provided aspects of 'homeland security', such as immigration, border controls, disaster management, Coast Guard and intelligence. ${ }^{15}$ The focus on transnational actors (especially terrorist groups) as security threats exemplifies this changing idea of security within the US security community. The identification of transnational threats preceded 9/11, seen in a variety of activities, from President Reagan's 'war on drugs' to President Clinton's focus on transnational crime (Andreas, 2003). However, the creation of the DHS radically alerted the institutionalisation of these efforts, integrating a number of the organisations already involved in the security effort of transnational actors (such as the Coast Guard, Customs Service and INS), and by emphasising the focus on terrorism (Andreas, 2003: 92). As the 9/11 Commission put it, '9/11 has taught us that terrorism against American interests "over there" should be regarded just as we regard terrorism against America "over here." In this same sense, the American homeland is the planet' (2004: 362).

Moving from the official discourse to the academic, one of the more interesting ways that this environment of global insecurity has been characterised is as a 'world risk society'. Risk, according to Beck, means 'the modern approach to foresee and control the future consequences of human action' (Beck, 1999: 3; c.f. Boyne, 2003). In this sense, risk is mainly about knowing the possible consequences of actions, and trying to control them. The argument is that globalisation has increased the intensity and scope of risk. These risks can range from the extremely local (e.g. ontological insecurity of the self) to the global (e.g. risks of nuclear war) (Giddens, 1990).

Coker uses the sociological literature on risk to illuminate the contemporary world of security and insecurity: 'risk increasingly determines the discourse of security' (Coker, 2002: 60). The importance of this thinking is that it demonstrates how risk and insecurity is more and more perceived to be occurring at a global level. The problems society faces are no longer just part of their immediate community. As Coker states, 'globalisation has drawn us out of our self-contained national or local communities into a larger world that offers none of 
the old protections' (Coker, 2002: 59). Overall, viewing the world as a risk community shows the broadest possible meaning of a globalisation of security, demonstrating that risk (and danger?) is part of the world we live in.

The terrorist attacks on 9/11 have been intimately connected with globalised risk. For example, Cronin argues that the context of globalisation has resulted in the exploitation of new methods of terror: 'important changes in terrorist methods are apparent in the use of new technologies, the movement of terrorist groups across international boundaries, and changes in the sources of support' (Cronin, 2003: 46; c.f. Adamson, 2006; Tirman, 2004). The identification of a new context of threat that fits into ideas about globalisation and risk, was crucial to the refashioning of the security discourse. This was especially clear concerning new ideas about the role of borders.

In traditional approaches to security, which are defined by realism, borders are crucial to security: threat is externalised, and the significance of borders is the protection of the territorial state. ${ }^{16}$ While this position on security has great importance, it does not recognise the possibility that such ideas about security change over time. As Andreas summarises, 'as a result, there is a widening gap between the traditional realist conception of security of borders and what many states are actually doing in the realm of security and border defences' (Andreas, 2003: 82). The move away from defining the borders of security in terms of military threat, or just in terms of preparation for war, moved towards a redefinition of borders and security in terms of policing and transnational law. With the continuing relevance of globalisation, in terms of creating a global risk environment, the actual practices of security have moved away from this highly militarised concept of security, towards what could only be described as policing (Andreas and Price, 2001). This is not to say that military security has become irrelevant, but in advanced industrial democracies, interstate war has become less relevant, and militaries are increasingly becoming more like police forces.

The connections to globalisation go deeper than just concerning protection from terrorism The problems the DHS faces are reshaping borders as filters, in order to allow the beneficial movements of the products of economic globalisation (be they shipped goods or movements of people) while excluding the 'undesired' (Flynn, 2003; c.f. Naim, 2005). Overall, the DHS 
has played a major role in institutionalising the new risk environment, at its most basic defined by the context of globalisation and the movement of people and goods across borders. While this necessitates a re-inscription of borders as barriers, it also adds a dimension. As Bigo points out, 'security is not only a state affair, it is a boundary function' (Bigo, 2001: 91; c.f. Biersteker, 2003). However, instead of seeing borders as solid barriers, that can be easily guarded from external threats, in a global risk environment security is everywhere.

\section{Conclusion}

The creation of the Department of Homeland Security should be taken quite seriously as providing a shift in the discourse of security, and in the overall perception in the US concerning what security fundamentally is. While the creation of the DHS has not put an end to the pursuit of national security through military means, the broad context of security has shifted to come to terms with the context of a global risk environment. That such an environment requires a new policy approach to the pursuit of security is no surprise. In the broad context of the actual implementation of security, risk management and policing functions are becoming more prominent in dealing with the context of globalisation. The securitisation and subsequent institutionalisation of this new environment of threat is of utmost importance for security analysts.

However, there is also a real paradox here: as military and policing functions become more and more alike, the war on terror tends to be discussed in a very old-fashioned manner, even if the real frontline against terrorism is not through conventional conflict (e.g. the Afghan war, or even the Iraq war), but through intelligence efforts to close down terrorist finance channels, or through the policing of borders through the DHS. ${ }^{17}$ The rhetoric of war is odd in this respect, except in terms of the way in which it helps to mobilise society, or puts the new threats on very familiar grounds. ${ }^{18}$ The connection of the Bush administration's foreign and defence policy team with more traditional realist visions of security may be an important aspect here (Daalder and Lindsey, 2003). An example of this realism can be seen in a comparison of the security strategies of Presidents Bush and Clinton: the National Security 
Strategy of 2002 does not mention 'globalization', whereas the previous document, President Clinton's 'A National Security Strategy for a Global Age' made 19 references to the concept (White House, 2000; White House, 2002). ${ }^{19}$

The move towards a new concept of security has not been without its costs, especially in terms of the state-society relationship. In yet another parallel with the early Cold War, it has led to a resurrection of the 'garrison state' thesis proposed by Harold Lasswell in the 1950s (Lasswell, 1977). While Lasswell's extreme predictions about the concentration of specialists of violence in government did not come true, the idea of a state that is mainly led by its military (concerns) is still important. As Morgan points out, 'the nexus between civil defence, military force, and disaster response have led to the fulfilment of Lasswell's argument that specialists of violence will train in skills that we have traditionally accepted as part of modern civilian management' (Morgan, 2004: 7). The creation of the DHS, in combination with legislation such as the USA-Patriot Act, have led to real concerns over the influence of the state on domestic freedom; also a concern about the influence of military concerns on politics and policy, as military-civilian relations have taken a new turn. The severe concentration of power that conservatives had warned against with the National Security Act have now been deepened, especially in the context of a 'war on terror': 'there is a striking similarity between his central theoretical problem and the practical problems of sustaining civil liberties while facing the challenge of an active crisis of national security with no apparent end' (Morgan, 2004: 7).

While the Cold War national security state, led by the institutional reforms of the National Security Act, did not lead to Lasswell's garrison state (mainly due to anti-statist tendencies within the US), ${ }^{20}$ some of the features that were institutionalised affected the way security could be discussed within the US, marginalizing other approaches. However, the lag in thinking about security is not surprising, as even new institutions take a while to become embedded. The DHS has only been in existence for four years, and will continue to play a role in defining the borders of US security in the future. The gradual modification of military roles towards policing also continues apace, despite the perceived foreign and security policy focus on inter-state relations. Time will only tell if the legacy of the DHS is comparable to 
the set of institutions created by the National Security Act, and whether or not those Cold

War institutions face pressures for reform inaugurated by the challenges of globalisation.

\section{Endnotes}

${ }^{1}$ I would like to thank Barrie Axford for organizing the workshop where this paper was originally presented, and for arranging this special issue. I would also like to thank all of the participants in the original workshop, and the two anonymous referees, who all provided valuable comments on the original presentation and draft.

${ }^{2}$ In his speech for the signing of the Act, President Bush made the connection explicit: 'setting up the Department of Homeland Security will involve the most extensive reorganization of the federal government since Harry Truman signed the National Security Act' (Bush, 2002).

${ }^{3}$ For the impact of the National Security Act, in the context of the early Cold War, see Hogan (1998).

${ }_{5}^{4}$ See, for example, Gray (2002).

${ }^{5}$ This can be seen in the bracketing off of the state that many constructivist (and mainstream) IR scholars engage in. For a general criticism of this tendency, see Wight (1999).

${ }^{6}$ There is some overlap here with Agamben's work on the 'state of exception'; see Agamben (2005). Along these lines, Williams (2003) has clearly located the thematic similarity between the 'Copenhagen school' and Carl Schmitt, especially in terms of the 'politics of enmity, decision, and emergency which has deep roots in Schmitt's understanding of political order' (515).

${ }^{7}$ This is to imply that threats are ontologically intersubjective, but epistemologically objective. See Searle (1995) and Hacking (1999).

${ }^{8}$ This draws from Hacking's discussion of social construction: Hacking (1999: 21-24).

${ }^{9}$ Croft (2006) has made a similar argument (also regarding 9/11) linking ideas about crisis, discourses of threat and institutional development.

${ }^{10}$ Historical institutionalists have addressed such issues through the analysis of critical junctures and developmental pathways: the former focusing on founding moments of institutions, the latter on feedback effects and evolution of institutions (Thelen, 1999; c.f. Pierson, 2004).

${ }^{11}$ Williams (2003) has commented on how this feature makes these events somewhat different to the past.

${ }^{12}$ This is not to say that there were not advocates of putting terrorism to the top of the security agenda. See, for example Clarke (2004). The 1999 Hart-Rudman Commission had also made similar recommendations regarding terrorism to those made after $9 / 11$, such as the development of a specific department dealing with homeland defence.

${ }^{13}$ Many of these emergency measures are beginning to be questioned, particularly over the expansion of executive power. See the overview in Ornstein and Mann (2006). Croft (2006: chap. 5) also includes the development of contradictions in the consensus surrounding a crisis discourse as a crucial part of his explanatory model.

${ }^{14}$ The phrase is from Carter (2001). Croft (2006) also discussed the DHS in the context of institutionalising the 'war on terror', though as one part of three aspects of institutionalisation.

${ }^{15}$ See the details in the DHS' two key documents Office of Homeland Security (2002) and DHS (2004).

${ }^{16}$ The classic reading of security and territoriality can be found Herz (1957). Ruggie (1993) provides an important update.

${ }^{17}$ See Cronin $(2002 / 03)$ for a critique of the current policy along these lines.

${ }^{18}$ On the problem defining the effort against terrorism as a 'war', see Howard (2002).

${ }^{19}$ It is possibly telling that the 2006 report has a whole section on the challenges of globalisation.

${ }^{20}$ As argued in Friedberg (2000). However, see the review of Friedberg's book in Sherry (2003).

\section{References}

Adamson, Fiona B. (2006) 'Crossing Borders: International Migration and National Security’, International Security 31 (1): 165-199.

Adler, Emanuel and Michael Barnett (eds) (1998) Security Communities. Cambridge: Cambridge University Press. 
Agamben, Giorgio (2005), State of Exception, trans. by Kevin Attell, Chicago: University of Chicago Press.

Andreas, Peter (2003) 'Redrawing the Line: Borders and Security in the Twenty-first Century', International Security 28 (2): 78-111.

Andreas, Peter and Richard Price (2001) 'From War Fighting to Crime Fighting: Transforming the American National Security State,' International Studies Review 3 (3): $31-52$.

Beck, Ulrich (1999), World Risk Society. Cambridge: Polity.

Berger, Thomas U. (1996) 'Norms, Identity, and National Security in Germany and Japan', in Peter J. Katzenstein (ed) The Culture of National Security, pp. 317-356. New York: Columbia University Press.

Biersteker, Thomas J. (2003) 'The Rebordering of North America? Implications for Conceptualizing Borders after September 11', in Peter Andreas and Thomas J. Biersteker (eds) The Rebordering of North America, London: Routledge.

Bigo, Didier (2001) 'The Möbius Ribbon of Internal and External Security(ies)', in Mathias Albert et al., eds., Identities, Borders, Orders (Minneapolis: University of Minnesota Press, 2001).

Boyne, Roy (2003) Risk. Milton Keynes: Open University Press.

Bush, George W. (2001) 'Address to a Joint Session of Congress and the American People,' September 20, 2001

Bush, George W. (2002) 'Remarks by the President at the Signing of H.R. 5005 the Homeland Security Act of 2002.' Retrieved from :http://www.whitehouse.gov/news/releases/2002/11/20021125-6.html

Buzan, Barry, Ole Waever, and Jaap de Wilde (1998) Security: A New Framework for Analysis. Boulder, CO: Lynne Rienner.

Carter, Ashton B. (2001) 'The Architecture of Government in the Face of Terrorism', International Security Vol. 26, No. 3: 5-23.

Checkel, Jeffrey T. (1998) 'The Constructivist Turn in International Relations Theory', World Politics 50 (2): 324-348.

Clarke, Richard A. (2004) Against All Enemies. New York: Free Press.

Coker, Christopher (2002) Globalisation and Insecurity in the Twenty-first Century: NATO and the Management of Risk. Adelphi Paper 345. Oxford: Oxford University Press.

Croft, Stuart (2006) Culture, Crisis and America's War on Terror. Cambridge: Cambridge University Press. 
Cronin, Audrey Kurth (2002/03) 'Behind the Curve: Globalization and International Terrorism', International Security 27 (3): 30-58.

Daalder, Ivo H. and James M. Lindsay (2003) America Unbound: The Bush Revolution in Foreign Policy. Washington: Brookings.

Department of Homeland Security (2004), Security our Homeland: U. S. Department of Homeland Security Strategic Plan, Washington, D.C.: Department of Homeland Security.

Desch, Michael C. (1998) 'Culture Clash: Assessing the Importance of Ideas in Security Studies', International Security 23 (1): 141-170.

Farrell, Theo (2000) 'Constructivist Security Studies: Portrait of a Research Program', International Studies Review 4 (1): 49-72.

Flynn, Stephen E. (2003) 'The False Conundrum: Continental Integration versus Homeland Security', in Peter Andreas and Thomas J. Biersteker (eds) The Rebordering of North America. London: Routledge.

Friedberg, Aaron L. (2000) In the Shadow of the Garrison State: America's Antistatism and its Cold War Grand Strategy. Princeton: Princeton University Press.

Gaddis, John Lewis (1987) 'The Insecurities of Victory: The United States and the Perception of Soviet Threat After World War II', in The Long Peace, pp. 20-47. Oxford: Oxford University Press.

Gaddis, John Lewis (2004) Surprise, Security, and the American Experience. London: Harvard University Press.

Giddens, Anthony (1990) The Consequences of Modernity. Cambridge: Polity.

Goldstein, Judith and Robert O. Keohane (1993) 'Ideas and Foreign Policy: An Analytic Framework', in Judith Goldstein and Robert O. Keohane (eds), (1993) Ideas and Foreign Policy: Beliefs, Institutions and Political Change. Cornell University Press.

Gray, Colin S. (2002) 'World Politics as Usual after September 11: Realism Vindicated', in Ken Booth and Tim Dunne (eds) World in Collision. London: Palgrave.

Guzzini, Stefano (2000) 'A Reconstruction of Constructivism in International Relations', European Journal of International Relations 6 (2): 147-182.

Hacking, Ian (1999) The Social Construction of What? Harvard: Harvard University Press.

Hay, Colin (2002) Political Analysis. London: Palgrave.

Herz, John (1957) 'The Rise and Demise of the Territorial State', World Politics 9: 473-493.

Hobson, John (2000) The State and International Relations. Cambridge: Cambridge University Press. 
Hogan, Michael J. (1998) A Cross of Iron: Harry S. Truman and the Origins of the National Security State 1945-1954. Cambridge: Cambridge University Press.

Hopf, Ted (1998) 'The Promise of Constructivism in International Relations Theory', International Security 23 (1): 171-200.

Howard, Michael (2002) 'What's in a Name? How to Fight Terrorism', Foreign Affairs 81 (1): 8-14.

Ikenberry, G. John (1993) 'Creating Yesterday's New World Order: Keynesian 'New Thinking' and the Anglo-American Postwar Settlement', in Judith Goldstein and Robert O. Keohane eds., Ideas and Foreign Policy: Beliefs, Institutions and Political Change. Ithaca: Cornell University Press.

Ikenberry, G. John (2001), After Victory: Institutions, Strategic Restraint, and the Rebuilding of Order After Major Wars. Princeton: Princeton University Press.

Johnston, Alastair Iain (1995) 'Thinking about Strategic Culture', International Security 19 (4): 32-64.

Katzenstein, Peter J. (ed) The Culture of National Security. New York: Columbia University Press.

Lasswell, Harold (1977) 'The Garrison State', in Dwaine Marvick ed., Harold D. Lasswell on Political Sociology. Chicago: University of Chicago Press.

Leffler, Melvyn P. (2003) '9/11 and the Past and Future of American Foreign Policy', International Affairs 79 (5): 1045- 1063.

Locher, James (2003) Victory on the Potomac: The Goldwater-Nichols Act Unifies the Pentagon. Texas A\&M University Press.

Mann, Michael (1986) The Sources of Social Power, Vol. I. Cambridge: Cambridge University Press.

March, James G. and Olsen, Johan P. (1984) 'The New Institutionalism: Organisational Factors in Political Life', American Political Science Review 78 (3): 734-749.

March, James G. and Olsen, Johan P. (1998) 'The Institutional Dynamics of International Political Orders', International Organization 53 (4): 943-969.

Morgan, Matthew J. (2004) 'The Garrison State Revisited: Civil-Military Implications of Terrorism and Security', Contemporary Politics 10 (1): 5-19.

Naim, Moises (2005) Illicit: How Smugglers, Traffickers and Copycats are Hijacking the Global Economy. New York: Doubleday.

National Commission on Terrorist Attacks upon the United States (The 9/11 Commission) (2004) Final Report. New York: W. W. Norton. 
Office of Homeland Security (2002), National Strategy for Homeland Security, Washington D.C.: Office of Homeland Security

Ornstein, Norman J. and Thomas E. Mann (2006) 'When Congress Checks Out', Foreign Affairs 85 (6): 67-82.

Pierson, Paul (2004) Politics in Time: History, Institutions, and Social Analysis. Princeton: Princeton University Press.

Ruggie, John Gerard (1993) 'Territoriality and Beyond: Problematizing Modernity in International Relations', International Organization 47: 139-174.

Searle, John (1995) The Construction of Social Reality. Harmondsworth: Penguin.

Sherry, Michael S. (2003) 'A Hidden-Hand Garrison State?', Diplomatic History 27 (1): 163166.

Stuart, Douglas T. (2003) 'Ministry of Fear: The 1947 National Security Act in Historical and Institutional Context', International Studies Perspectives 4 (3): 293-313.

Tannenwald, Nina (1999) 'The Nuclear Taboo: The United States and the Normative Basis of Nuclear Non-Use', International Organization 53 (3): 433-468.

Thelen, Kathleen (1999) 'Historical Institutionalism and Comparative Politics', Annual Review of Political Science 2: 369-404.

Tirman, John (ed) (2004) The Maze of Fear: Security and Migration after 9/11. New York: Free Press.

Waever, Ole (1995) 'Securitization and Desecuritization', in Ronnie D. Lipschutz (ed) On Security, pp. 46-86. New York: Columbia University Press.

Waever, Ole, Barry Buzan, Morten Kelstrup, et al. (1993) Identity, Migration and the New Security Agenda in Europe. London: Pinter.

Weldes, Jutta et al. (1999) 'Introduction: Constructing Insecurity', in Jutta Weldes et al., eds., Cultures of Insecurity: States, Communities and the Production of Danger. Minneapolis: University of Minnesota Press.

White House (2000) A National Security Strategy for a Global Age. Washington: 2000.

White House (2002) National Security Strategy of the United States of America. Washington: 2002

Wight, Colin (1999) 'They Shoot Dead Horses don't They?: Locating Agency in the AgentStructure Problematique', European Journal of International Relations 5 (1): 109-142.

Williams, Michael C. (2003) 'Words, Images, Enemies: Securitization and International Politics', International Studies Quarterly 47 (4): 511-531. 
Woodward, Bob (2002), Bush at War. New York: Simon and Schuster. 